has behaved differently under tectonic squeezewhich was very severe in the trans-Indus area and almost absent in the Punjab area. Thesalt deposits are probably of the same age-laid down in Cambrian and pre-Cambrian times. They were protected by overlying strata until comparatively recent times, when erosion in the Punjab area and dynamic folding in the Kohat region have disclosed these valuable deposits, which have been preserved for us since the Lower Palæozoic age. The treatment of the plastic salt in the folded strata will fully explain how it escaped upwards along a fault into an anticlinal; also how it was carried upwards or became entangled with newer strata-nummulitic limestone, oil shale or pyritiferous coal ; and further, how when conditions and material were favourably disposed, gypsum has formed-from the included or xenolithic fragments in the rock-salt or adjacent to it in the strata from which the xenoliths were derived. The modus operandi in the Punjab area was somewhat different; it consisted of subsidence by solution and transport by underground water, whereby blocks of stone, tree stems and other derived material (such as microfossils and heavy minerals) have become embedded in the salt and in its insoluble residue (the kallar) in the Saline series of the Punjab areas. In neither case, however, cis- or trans-Indus, are these incorporated materials strictly in situ, and thus any gypsum formed from such derived material is, so to speak, truly tertiary, but in a primary setting.

In conclusion, I would like to quote a few lines from the last report submitted to the Government of India by Mr. H. B. Medlicott, director of the Geological Survey of India, before he retired in $1886^{7}$. He wrote :

"... The geologist's work is therefore sound and useful or false and misleading in proportion to his real acquaintance with the actuals and the principles of the exact sciences, and unless he reaches a certain standard of excellence his work is absolutely useless, or worse. In this respect the geologist is unique. A doctor may acquire a useful skill in the practice of medicine without being anything of a biologist : an engineer may do fair work with little or no knowledge of mechanics; a man may be a surveyor ... . without any proper knowledge of geodesy or astronomy: because in all these businesses there are practical rules by which ordinary work can be safely executed. . . Geology is the opposite of all this: there is no operation called for : every act in its service is an independent judgment upon very complex inductive facts through an accurate knowledge of physical phenomena and their laws ; if not scientific it is nonsense. Further it is to be noted that the data upon which the geologist has to frame his judg. ments are for the most part very scanty : from occa. sional scattered sections or single outcrops he has to attempt the representation of the rocks as they lie underground and their remote history. Thus, though based on the exact, it is itself the most inexact of sciences, and eminently demands conscientious and sober judgment. There is no science with which it is so easy to acquire a superficial acquaintance and to play the impostor. ..."

' See Rec. Geol. Surv. India, 61, Pt. 2 (1928), pp. 147-179, with plates $2-17$ showing various views of plastic marls, tilted strata and subsidences.

${ }^{2}$ Current Sci., 3, No., 9 (March 1935).

${ }^{3}$ Nature, 153, 462 (1944).

- Rec. Geol. Surv. India, 24, 19 (1891).

${ }^{5}$ Rec. Geol. Surv. India, 44 (1914); 50 (1919).

" "Manual of the Geology of India", Pt. 2, Extra-Peninsular Area, p. 487 (1878).

${ }^{7}$ Rec. Geol. Surv. India, 20 (1887), Annual Report for 1886, p. II.

\section{SCIENCE IN PEACE}

$\mathrm{T}$ HE most striking characteristic of the open conference on "Science in Peace", organized by the Association of Scientific Workers at Caxton Hall, Westminster, on February 17 and 18, was neatly expressed by Prof. J. D. Bernal in his final summing. up of the Conference. The content of the fifteen papers submitted in three sessions devoted respectively to "Science and Production" (chairman, Prof. P. M. S. Blackett), "The Future Development of Science" (chairman, Sir Robert Watson-Watt) and "Science in Everyday Life" (chairman, Prof. H. Levy) had, he said, had the quite remarkable quality of having been 'orchestrated'. An account of the whole opus will accordingly be attempted here, not by separate discussion of the component movements, but by tracing the leit-motiv which recurred so clearly, inevitably and appropriately through all. They are all familiar themes enough; but their interrelations took new emphasis, and their combined intellectual and emotional appeal was profound. They were expansion, investigation, documentation, publication (the key theme in some expected and some less expected contexts), organization, integration, mechanization, standardization, nationalization.

The Conference opened appropriately with a paper on "The Future of British Economy", by G. D. N. Worswick, and closed equally appropriately with one on "The Place of Science in Culture", by Prof. B. Farrington. The whole argument of the Conference was necessarily based on an expansionist economy providing full employment ; the practicability of continuous full employment is in large measure governed by the full utilization of science, including the scientific control of processes ; on the other hand, potentially revolutionary applications of science in industry are only acceptable to the workers if their justifiable fears about continuity of employment are categorically answered by a declared Government policy for assured and continuous full employment. The honouring of such an assurance depends on giving to the public interest its rightful place relative to private interest, and this in turn can only be assured by a substantial measure of Government control. No point made was more heartily applauded than the statement that bureaucracy is far more prominent and harmful in the larger aggregations of 'private' enterprise than in Government departments. Government control, varied and adapted to the needs of public interest in application to each main industry, must be control by the people acting through a democratic government in the interests of the people. The overall success of government control in the greatly expanded industry of the war effort was cited as an augury for the future.

The paper by Mr. Joe Scott, member of the Executive Committee of the Amalgamated Engineering Union, on "Science and the Productivity of Labour", emphasized the role of science in improving the conditions of life of the worker while at work and at leisure, in lightening labour and improving the use of leisure, in avoidance of injury and improvement of health. $\mathrm{He}$ stressed the inseparability of science from production; it was another of the recurrent themes of the Conference that we are no longer dealing with separable applications of science to industry; that we are now at a stage where scientific method should be inherent in every step of the industrial process, where the permeation. of science through the whole of industry is a happily 
irreversible process preventing the picking out of samples to be exhibited as 'science in industry'. This permeation of process demands a corresponding permeation of organization, in which the place of scientific work in the national economy is recognized and ensured by detailed interlacing in an industrial democracy, at all levels and in all significant groupings. An important element in this permeation is a much closer co-working with the trade unions, individually and collectively.

Mr. Scott introduced the two themes of investigation and documentation, with examples of welfare and health investigations, which could not have been carried through save by the machinery of the trade unions and shop stewards; and, from another angle, with a plea for direct availability to trade union negotiators of the scientific and technical facts which they require to support and answer statements made in negotiation.

This was one aspect of a universal demand for public availability of the facts-many already known privately, many not yet known even to managements in private enterprise-by which the efficiency and potential of any stage in the industrial process can be measured. The filling of the gaps in private and public information is essential to progress, and involves the large application of the methods of operational research within industries. There is need, indeed, not merely for organized research but also for research on organization; the appropriate structures for scientifically operated and publicly controlled industry are still in large measure unknown or illunderstood.

The demand for publication as a safeguard of the public interest was pressed at every session and thus in many different connexions. If it were necessary or desirable to condense in four words the essence of the discussion on "Science in Everyday Life", the words might well be "Publish and be Blessed". Full and free interchange of knowledge not only from scientific research, but also from studies on organization, not only on engineering efficiencies but also on economic efficiencies, 'all facts on the table' was regarded as essential to increased productivity, to improved conditions of life, and to the avoidance of diversions in favour of private interests.

"The Organisation and Finance of Science" were discussed by Dr. S. Lilley, who argued the case for the Association of Scientific Workers policy in favour of a national research and development council, responsible to the Lord President of the Council, for surveying national needs and resources and planning the broad lines of scientific work to meet the needs and develop the resources. The Council would plan the strategy of attack on these problems; it would neither execute the work in laboratories of its own nor interfere in the tactics of work in the laboratories, of existing types, to which it would allocate broad responsibilities and adequate finance. Expenditure at the rate of some twenty-four million pounds per annum, as compared with our pre-war seven million pounds per annum, it was stated, is required; a great expansion of laboratories would be needed; the research associations would be key factors in the plan, and no industry would be allowed to stifle co-operation by the withholding of financial contributions ; the naive form of subsidy-without-supervision represented by tax remission on alleged research should not be permitted; publication of results would be insisted on. The new organization would require the participation of the representatives of the people in general, and of the scientific worker in particular, at all levels in the formation and execution of policy.

An important part of the problem of the deploy. ment of our scientific forces is the striking of a balance between long-term fundamental work and short-term work of direct and immediate application. The chairman of the session on "The Future Development of Science" described the problem as one in the "intellectual economics of the social conscience"; Prof. Blackett emphasized the high long-term productivity of fundamental science, which must pass from its old state of self-determination towards an imposed orientation arising from increased direct support from public funds. This fundamental science must be guided by men of science, acting under broad directives on social objectives coming not from a bureaucratic Civil Service but from public opinion through Parliament and the Government answering to Parliament. An important part of this direction must rest on the economic policy adopted by the nation; there is virtually no limit to what science can do; there are limits set by economics on what it is worth doing, for example, in developing synthetics and substitutes as an alternative to importing. A short-term crisis, such as the present War, is the only exception to the law which forbids the sacrifice of the big future dividends offered by fundamental research to the smaller quick returns of too closely applied development.

Both Sir Robert Watson-Watt and Prof. Blackett directed attention to the need for a federation which could speak with the voice of the scientific practitioner at large; on a wider basis than the highly selective Royal Society and the highly specialized professional institutions; including the Association of Scientific Workers, with its vitally important trade union affiliation, but not excluding those who do not recognize that affiliation as necessary or desirable.

Prof. Bernal, in his contribution on the future development of "Applied Science and Technology", carried the development of the theme of 'organization' into the enunciation of the theme of 'integration'. The application of science is the practical side of the war against poverty and calls for the same spirit and intensity of organization as the current War. The revolution in the relations of science to industry is now far advanced; the essential now is the complete integration of science with industry; the dual problem is to make industry scientific through and through, and to make this possible by demonstrating to the public the need for this permea tion and integration. The public has still far to go in appreciation of the need : it is still merely 'gadgetminded'.

This integration demands the full democratization of science in industry; democratization is far less advanced in industry than in politics. One necessary element, that of public criticism, is provided in the political sphere by Parliament; it could be provided in the sphere of industrial science by trade union organization. Only the scientific worker can determine the mode of application of science in industry; for this he must sit in the board room of management for the formation of policy, he must equally find his place in the joint production committee.

Integration, as was shown in those contributions to the first session which dealt with the basic industries of Britain, must be carried over the whole area of each industry and across the frontiers between industries; the separation of the generation of gas 
from the generation of electric power and of both from the full utilization of coal is as artificial, irrational and wasteful as is the treatment of the coal industry as something apart from the chemical industry, of which coal is the very foundation.

Discussion on the coal industry was the most important single development of the mechanization theme, and it led to the conclusion, not from any devotion to nationalization as a good-in-itself, but from lessons in the long unhappy history of that industry in particular, that mechanization in coalgetting would not be attained without governmental control so firm and detailed as to mean nationalization. The inapplicability of any such simple prescription as 'American machinery everywhere' was recognized; but there was a clear conviction that a plan of mechanization measured to the geology and the degree of past working is of extreme importance.

The discussions, which brought in variations on the theme of mechanization, interwove it so intimately with the theme of standardization that an answer to criticisms of 'dullness through standardization' was specially important. It was pointed out that general availability of the products of industry depends on the wide extension of mechanization, that mechanization can only be reasonably effective if the production runs are long runs giving large numbers of one pattern, and that consequently the total number of patterns available to the total field of consumption would be reduced. This does not, however, mean that the average consumer, with limited purchasing power, has a reduced range of available patterns. He would, in fact, have access to a wider range of better models, brought within his reach by the economies in cost attained through mechanization.

The Conference was made notable by the resumption of personal international contacts on a scale only now becoming possible as the war situation improves. The Sunday morning session was marked by the enthusiastic reception of addresses by Dr. Marcel Matthieu, a member of the executive committee of the French Association of Scientific Workers, and by Prof. A. Danilov, chairman of the U.S.S.R. trade union covering scientific and ancillary workers in the laboratories of the universities, the aeademies of science and the research institutes. Prof. Danilov was accompanied by four other Soviet colleagues; it was noteworthy that the Soviet delegation to the World Trade Union Congress meeting in London included three scientific workers.

The Conference adopted at its closing session a resolution in the following terms :

"This public conference which has met to consider the tasks of science after the war, records its wholehearted admiration of the fighting forces of the United Nations whose great achievements are bringing peace nearer at hand. Their deeds are providing the foundations for a better world while the advance of science and technique are the tools with which it can be built. This conference declares its conviction that :

(1) The achievement of a progressive rise in the standard of living of mankind needs the fullest use of science and technique within the frame-work of a world expansionist economy.

(2) An expansionist economy policy at home implies assistance to the backward and undeveloped countries to raise their productive level by the establishment of modern industry and scientific agriculture.

(3) In this country the advanced and efficient application of science requires democratic planning largely by scientists themselves. For this we propose a central research and development council under the authority of the Lord President of the Council.

(4) The problems facing the manual workers in the future, arising from the effect on their working conditions, of scientific and technical advances, demand close collaboration between the organized scientists and the rest of the Trade Union movement.

(5) The closest collaboration must be achieved between the people of all nations, including the fullest interchange of scientific and technical knowledge based on the contacts now being built between the scientists in Great Britain and the Dominions, the U.S.S.R., France and the U.S.A."

\section{NEWS and VIEWS}

\section{Chemical Engineering at Cambridge}

The period extending between the two World Wars has been remarkable for the advances made in what is usually term 3 ' 'technology', and it is especially in chemical technology that this development has been most rapid and spectacular. A scientific discovery in a chemical research laboratory may be the progenitor of a finished manufactured article, but the aims and objects of the discoverer and those of the manufacturer are quite different. Since the manufacturer is interested in producing an effect, and since also economics plays an important part in his considerations, it is clear that many steps alien to a pure research laboratory have to be taken after a discovery has been made before a plant is in actual operation. We are confronted with the problem as to the most suitable training for such workers in chemical technology. Prof. Haber, who was at Cambridge at the end of the War of 1914-18, when asked what English chemical industry needed, replied that our weakness lay in not applying the methods of physical chemistry to industry. There is more than a germ of truth in this. Chemical engineering may be regarded by some as a misnomer for chemical technology; and it is within the orbit of physics and chemistry rather than engineering that the new development should take place.

The larger industries in Britain can train their own men, but this is impossible in smaller units. The training given in the Technische Hochschulen on the Continent, or the Massachusetts Institute of Technology in the United States, has proved eminently successful in the respective countries. In Great Britain it appears that such further development as is required will take place in the universities. Hence the munificent gift of about half a million pounds by the Shell Group of oil companies to the University of Cambridge for the endowment of chemical engineering comes at an appropriate time. The University, in accepting this, has likewise incurred a great responsibility. It is generally recognized that we have much leeway to make up to survive in the post-war world as an industrial nation. The chemical industries of Britain are by no means 